\title{
The use of the transpedicular spinal system and titanium mesh cage in surgical treatment of post-traumatic pelvic deformity: a case study and a brief literature review
}

\author{
K.L. Zhalmagambetov ${ }^{1}$, S.O. Ryabykh ${ }^{1}$, A.S. Zhdanov ${ }^{1}$, A.V. Gubin ${ }^{2}$ \\ ${ }^{1}$ Ilizarov National Medical Research Centre for Traumatology and Orthopedics, Kurgan, Russian Federation \\ ${ }^{2}$ National Medical Research Center of Traumatology and Orthopedics n.a. N.N. Priorov, Moscow, Russian Federation
}

\begin{abstract}
Introduction The problem of treating chronic unstable pelvic injuries is characterized by the complexity of delayed onestep or staged reduction, difficulties in choosing the technology and treatment options, complexity of selecting criteria for evaluating planning along with the effectiveness of treatment. The use of spinal systems to perform reduction manipulations and fixation of the pelvis is described in few clinical observations. Therefore, the assessment of the effectiveness of the sequential use of various fixation systems in one patient was regarded by the authors as a rare opportunity and determined the purpose of the study. Purpose Demonstration of the possibilities of various osteosynthesis methods and their combination in reconstructive surgery of the pelvis in a case of its severe chronic injury. Materials and methods We present a clinical case and a brief analysis of the literature. This is a case of a patient with post-traumatic pelvic deformity and imbalance syndrome as a leading component of pelvic ring deformity. The effectiveness of reconstruction options, including those with the use of spinal systems, was analyzed. The treatment was assessed with radiological study methods (X-ray and CT) with balance evaluation on a digital platform and functional scores for the quality of life. Results Correction of frontal deformity of the pelvis was achieved with compensation for a relative shortening of the left lower extremity, restoration of the center of rotation of the hip joints, and relief of pain in the lumbar region. The functional state according to the Majeed score system and clear radiological signs of stabilization of the pelvic ring while maintaining the position of the acetabulum in the frontal plane prove the effectiveness of hybrid osteosynthesis with the use of spinal fixation systems. Conclusion The leading syndromic complexes are instability with clinical manifestations of non-union and pain along with an imbalance syndrome, manifested by a gross deformation of the pelvic ring. Syndromic evaluation determines the tactics of surgical treatment while a detailed planning of the sequence of intervention, choice of the level of osteotomy, combination of osteosynthesis options using spinal fixation systems provide the solution of reconstructive pelvic surgery tasks in one session.
\end{abstract}

Keywords: post-traumatic pelvic deformity, transosseous osteosynthesis, transpedicular fixation system, defect, titanium mesh cage

\section{BACKGROUND}

Pelvic fractures are referred to the most severe injuries of the musculoskeletal system. As reported, the frequency of pelvic injuries in the structure of highenergy trauma is $5-25 \%[1-7]$. Severe general condition of such patients in the acute period is an obstacle for early reconstructive operations on the musculoskeletal system. Surgical operations aimed at restoring vital organ functions come first $[2,9]$. Due to the introduction of the ATLS and damage-control protocols the number of surviving patients with pelvic injuries has increased and, consequently, post-traumatic pelvic pathology and the number of secondary complications of their treatment also have grown [8].

Conservative treatment methods lead to improper consolidation of the pelvic bones and instability of the pelvic ring in $38-75 \%$ of cases [3, 5, 10-12], and to persistent disability in 30-65\% of cases, mainly in the patients of working age [13-15].

Pelvic fractures with a period of more than three weeks since injury are difficult to reduce due to the formation of callus and soft tissue traction. A particular problem is treatment of chronic unstable pelvic injuries, in which one-stage reduction is frequently impossible due to its delay [16].

At present, the tactics of treating patients with posttraumatic deformities of the pelvic bones has not been solved. In the absence of the established guidelines and management protocols, methodological options depend on institution schools, and range from conservative therapy to multiplanar reconstructive interventions. The fixation options are also various. Osteosynthesis has been widely used both with external fixation devices and in combination with osteotomy of the pelvic bones with subsequent conversion to internal osteosynthesis [17].

Most questions arise in the treatment of patients with a combination of pelvic deformity, defects and instability. We substantiated the main one as follows. What methods and options of fixation would enable to perform reconstruction and stabilization of the

Zhalmagambetov K.L., Ryabykh S.O., Zhdanov A.S., Gubin A.V. The use of the transpedicular spinal system and titanium mesh cage in surgical treatment of post-traumatic pelvic deformity: a case study and a brief literature review. Genij Ortopedii, 2021, vol. 27, no 1, pp. 97-103. DOI 10.18019/1028-4427-2021-27-1-97-103 
pelvic ring, decrease the treatment time and the risks of secondary instability? We hypothesized that the transpedicular spinal fixation system and a titanium mesh cage used for the reconstruction of the anterior and middle columns of the spine would be suitable for these purposes. As a result of using this technique, we present a clinical case.

Study design A case report and brief analysis of literature. Level of evidence - 4 (UK Oxford, 2009 version).

Case report A 21-year-old woman was admitted to the clinic of the Russian Ilizarov Research Center with complaints of gait disturbance, chronic pain in the lumbar spine and pelvic deformity.

The patient was injured 1.5 years prior to admission and sustained a closed fracture of the pubic and sciatic bones on the right, pubic and iliac bones on the left, rupture of the pubic and sacroiliac joints on the left with displacement of the left half of the pelvis upward, extensive lacerated wound in the area of the left knee joint and right thigh, traumatic neuropathy of the left sciatic nerve. The treatment at her residence hospital continued two months and included autodermoplasty of the right thigh and treatment of fractures of the pelvic bones

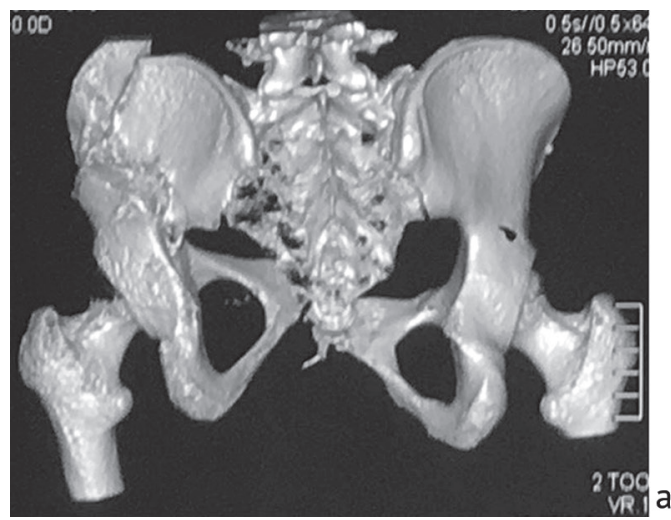

with skeletal traction through the tuberosity of the left tibia. In 2015, the patient was admitted for staged treatment to the clinic of the Russian Ilizarov Research Center for post-traumatic deformity of the pelvis, nonunion fracture of the wing of the left iliac bone, and rupture of the symphysis (Fig. 1). Upon admission, compression-ischemic neuropathy of the peroneal portion of the left sciatic nerve was also detected.

The anterior pelvic semiring was fixed with an external fixation apparatus (EFA) on 07.05.2015. On the left, the Schanz screws passed into the iliac wing through the nonunion zone. After 9 days (16.05.2015), a supra-acetabular osteotomy was performed on the left, the left femur was fixed with EFA, and additional transosseous screws were inserted into the wing and the body of the iliac bones.

In the postoperative period, the left hip joint was attempted to be brought down for 14 days. The support was dismantled from the left femur but the apparatus on the pelvis was left in the fixation mode. It was removed in an outpatient clinic two months later. This stage of treatment resulted in union of the left iliac bone but the deformity of the pelvic ring could not be corrected (Fig. 2).

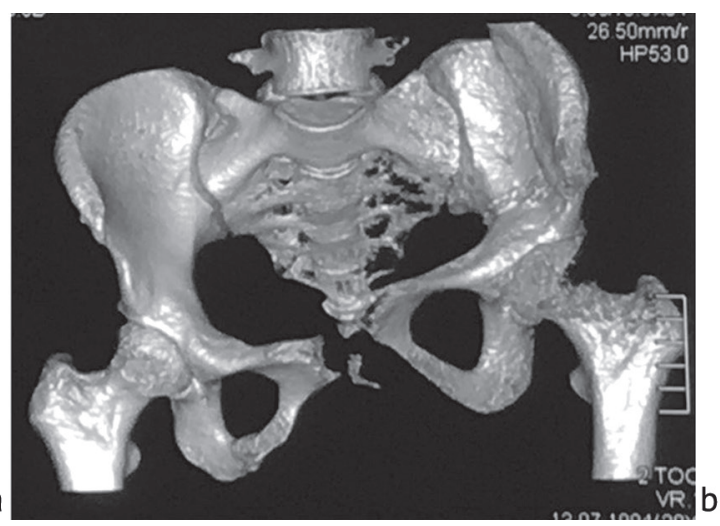

Fig. 1 Computed tomography of the pelvis before the first stage of correction; 3D reconstruction, ventral $(\boldsymbol{a})$ and dorsal (b) views. Craniodorsal displacement of the left acetabulum, rupture of the pubic articulation, rupture of the sacroiliac joint (SIJ) on the left, nonunion of a fragment of the left ilium wing are visualized
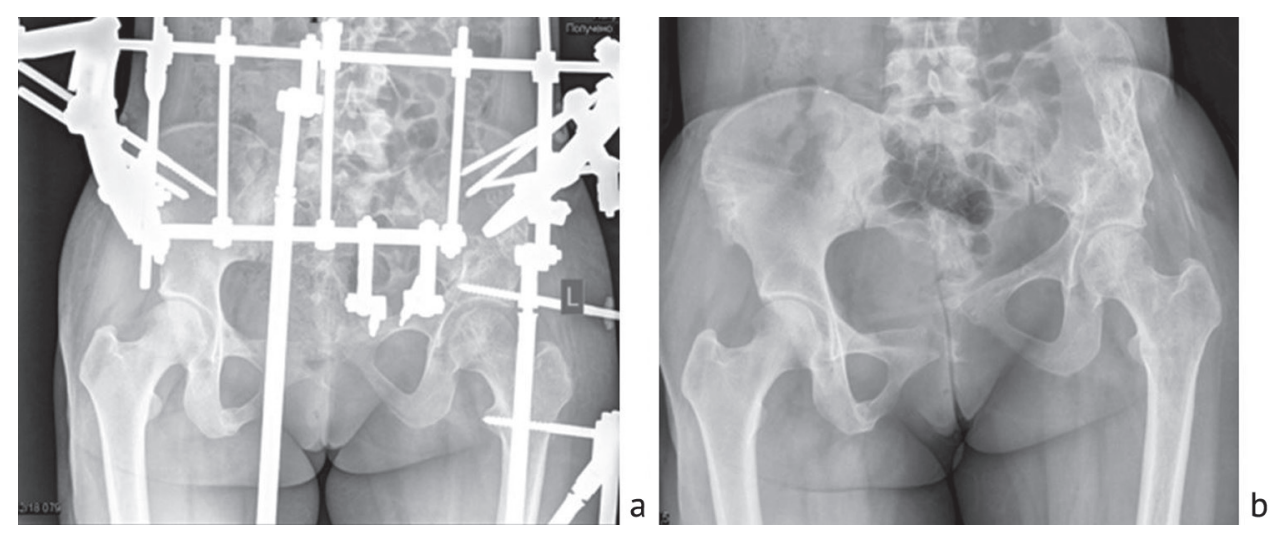

Fig. 2 Radiography of the pelvis in direct projection after surgery $(\boldsymbol{a})$ and at discharge $(\boldsymbol{b})$; union of the left iliac bone was achieved; pubic symphysis diastasis was $2.4 \mathrm{~cm}$; there was malunion of the left ilium and displacement of the left half of the pelvis upward 
Puncture implantation of epidural electrodes was performed on 05.02.2016 at the L4-L5 level to conduct electrical stimulation for neuropathy of the peroneal portion of the left sciatic nerve. There was no dynamics of the neurological status after the therapy.

On 25 April 2016, she was admitted to the clinic for the reconstruction of the pelvic ring and complained of left lower extremity shortening, pain in the lumbar spine (LS), and discomfort in the sitting position. At the time of hospitalization, the patient was walking with a cane. The asymmetry of the pelvis, a $2-\mathrm{cm}$ relative shortening of the left lower limb and the limitation of abduction in the left hip joint of about $30^{\circ}$ were visually noticeable. The range of motion in the left knee joint was $180^{\circ} / 90^{\circ}$. Also, there was a disturbance of superficial sensitivity on the dorsum of the left foot and on the lateral surface of the left lower leg. The Majeed functional state was 46 points. The patient underwent a radiographic examination of the pelvis in the frontal projection, entry and exit: there was a craniodorsal displacement of the left acetabulum and rupture of the pubic articulation.

Based on the patient's complaints of persistent pain in the lumbar area, relative shortening of the left lower extremity and radiographic views, a plan of surgical correction was developed implying an intraoperative elimination of the deformity of the pelvic ring, restoration of the center of rotation of the left hip joint; osteosynthesis of the left sacroiliac joint with cannulated screws to protect the SIJ when performing reduction manipulations; osteosynthesis with the Ilizarov apparatus in distraction mode at the stage of reduction; supra-acetabular osteotomy of the left iliac bone and bridging the defect in the left iliac bone with a titanium mesh cage with autologous bone; fixation of the hemipelvis with the spinal system [53].

Reconstructive and stabilizing intervention was performed on May 13, 2016.

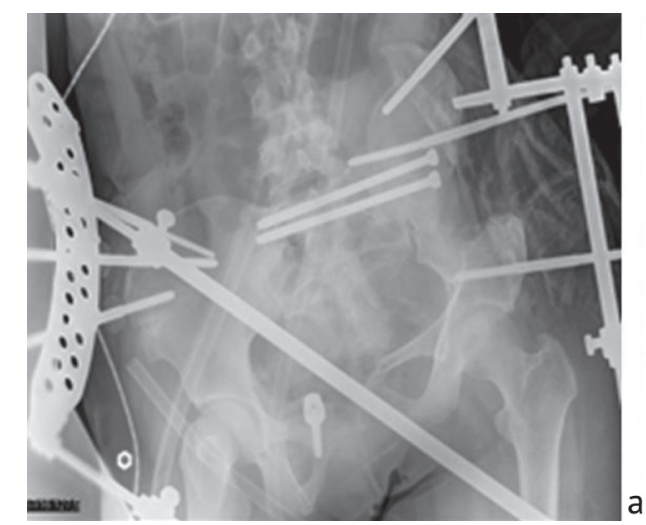

\section{Operation protocol:}

Stage 1 The surgical field was treated three times; the left sacroiliac joint was fixed with two cannulated ileosacral screws. Four diaphyseal half-pins (Shants screws) were inserted into the left femur. The screws were attached to a sectoral arch. Three screws were inserted into the iliac crest on the right, and two screws were inserted on the left above the planned osteotomy. The proximal support was assembled from sectoral arches and telescopic rods (Fig. 3a).

Stage 2 The iliac approach was performed. The area of the malunited ilium was exposed and mobilized on both sides. In the frontal plane in the supra-acetabular region, a half-pin was drawn and connected to the distal support. A supra-acetabular osteotomy of the pelvis was performed along the union line. X-ray control showed the osteotomy was produced correctly. To protect the hip joint, four $1.8-\mathrm{mm}$ wires were inserted transarticularly and attached to a ring on a distal support. Distraction along the rods was $9 \mathrm{~cm}$. Deformity of the pelvis in length and width was corrected. Radiographs showed a satisfactory position of the fragments. Diastasis was filled with a titanium mesh cage filled with pieces of autologous bone. Two polyaxial screws were inserted into the supra-acetabular region on the left, and two polyaxial screws were installed proximal to the osteotomy zone. The screws were fixed to two titanium bars.

Stage 3 Stoppa's approach was produced in the projection of the pubic bones. A fork-type screw was installed into the right pubic bone under the control of an image intensifier; the screw could not be inserted into the left pubic bone due to previously formed defects. A pedicle screw was inserted in the projection of the anterior lower spine on the left. The screws were fixed by the bar in the locking mode (Fig. 3b). the Arteries of the left lower limb were checked and their pulsation was not disturbed. The wounds were drained and sutured in layers. The skin was stitched. The AEF device was dismantled. Aseptic dressings were applied. The total blood loss was $800 \mathrm{ml}$.

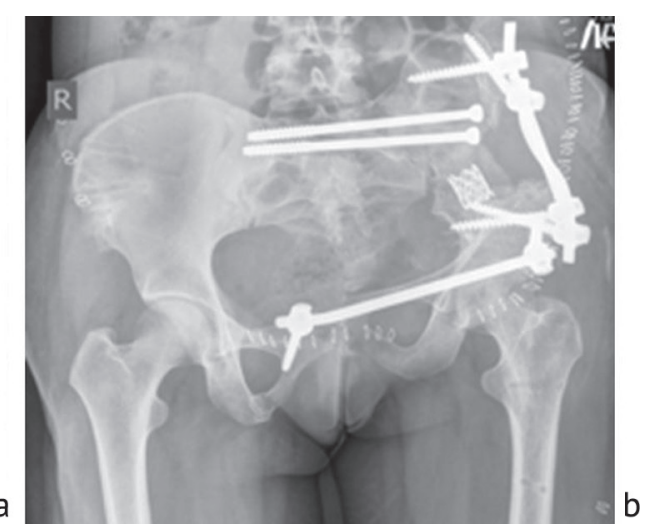

Fig. 3 Radiographs of the pelvis in direct projection at the stage of reduction unit from the set of the Ilizarov apparatus $(\boldsymbol{a})$ and after the reduction and fixation with the spinal system $(\boldsymbol{b})$ 

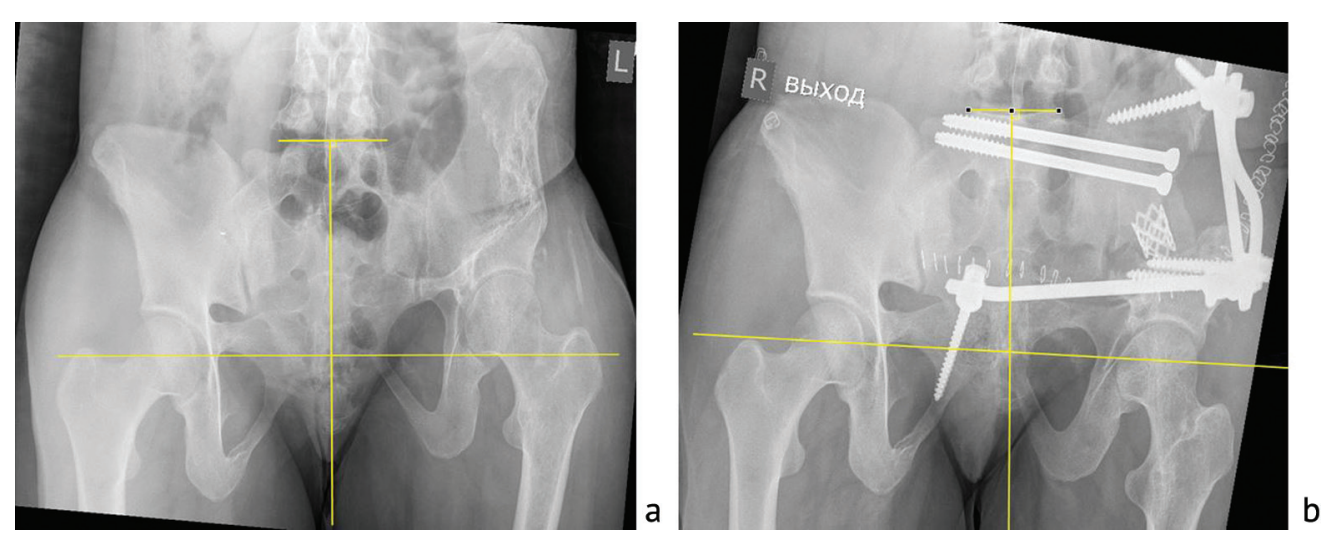

Fig. 4 Radiographs of the pelvis in frontal projection before surgery $(\boldsymbol{a})$, after reconstruction of the pelvic ring $(\boldsymbol{b})$. The position of the acetabulum in the frontal plane was restored
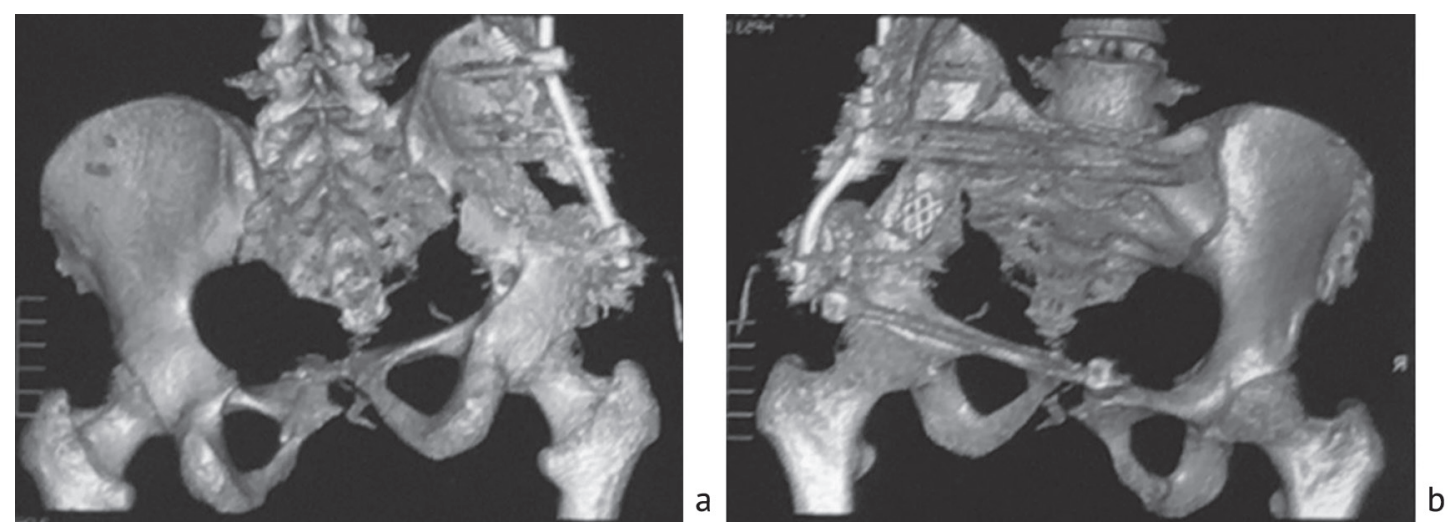

Fig. 5 Computed tomography of the pelvis after surgical reconstruction, 3D reconstruction, ventral $(\boldsymbol{a})$ and dorsal $(\boldsymbol{b})$ projections. The geometry of the left ilium was restored

The postoperative period was uneventful. The wound healed by first intention. The neurological status in the postoperative period did not worsen. The patient was verticalized on the $3^{\text {rd }}$ day. At discharge from the hospital on the $39^{\text {th }}$ day after the operation, she could independently move supporting on a cane, her gait style was restored.

In the postoperative period, the patient passed examinations at follow-ups. At the six-months followup, she did express any complaints, moved without additional means of support, and did not experience any discomfort by walking. The Majeed functional state was 90 points. On the checking plain radiograph dated 26.08. 2019, there were clear signs of stabilization of the pelvic ring and the position of the acetabulum in the frontal plane was preserved (Fig. 6).

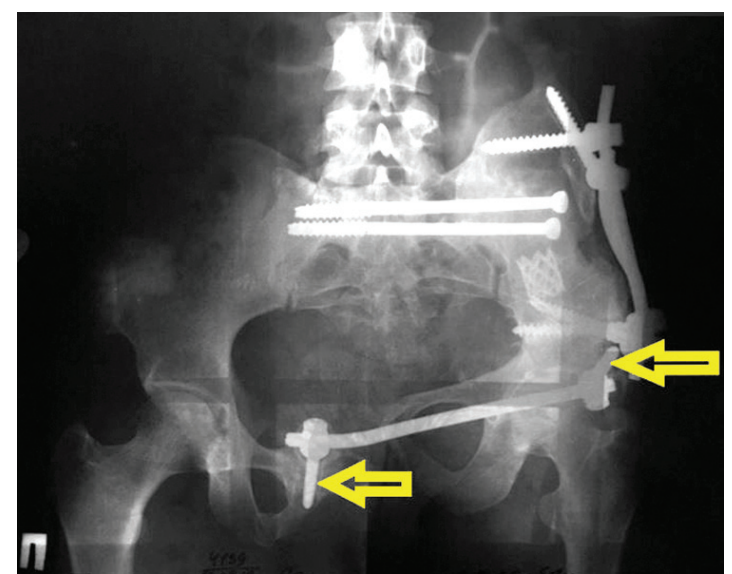

Fig. $6 \mathrm{X}$-ray of the pelvis in direct projection dated 26.08.2019. Remodelling of the left iliac autograft, bone resorption and malposition of screws fixing the anterior pelvic semiring

\section{DISCUSSION}

Pelvic ring injuries occur in 20-37 cases per 100 thousand people [18-20], in elderly patients up to 90 cases per 100 thousand [21]. Fractures of the pelvic bones, as reported, consitute from one to $8.2 \%$ of all fractures of the skeleton bones [18-20, 22, 24-27]. However, in polytrauma cases, the portion of pelvic injuries increases to $25 \%[2-6,18,24,28]$ and significantly contributes to mortality, up to $25 \%[25,29]$.

Road accidents (about $60 \%$ ) and falls from a height (6-28\%) are the main causes [18]. Older patients are characterized by osteoporotic fractures from low-energy trauma [19-21,23]. The most severe pelvic injuries are vertically unstable [28], occurring in $10 \%$ of cases [30]. The mortality rate in this group exceeds $80 \%$ [29].

Nonunion of the pelvic ring are more frequent, which, according to the localization of damage, are divided into nonunion of the anterior and posterior semirings of the pelvis. Union correlates with the displacement grade and stability of the pelvic 
ring [31]. Conservative treatment or placement of AEF in unstable injuries of the pelvic ring often results in malunion or nonunion [12, 29, 32, 33]. The most common nonunions are found in type $\mathrm{C}$ fractures according to Tile M. [2, 12, 34, 35]. Lindhal et al. cite the following data in patients with type $\mathrm{C}$ fractures treated with external fixation only: secondary displacement $57 \%$, deformity of the pelvic ring $58 \%$, nonunion of the pelvic bones $5 \%$; lateral compression rarely leads to nonunion of the posterior pelvic semiring [9]. Anteroposterior compression (APC) may lead to instability of the anterior semiring [7].

Pain is the most common complaint in patients with deformity and nonunion of the pelvic ring [12, 28, 29, $31,33,34,36-40]$. Thus, in a cohort study Mears et al. analyzed 204 cases of nonunion of the pelvic bones and $64 \%$ of the patients complained of severe pain [34]. Insufficient reduction and residual deformity after pelvic fractures lead to chronic pain and poor functional outcome [26, 41]. Instability in the posterior pelvis is the most common cause of pain. In most patients, the source of pain is damage to the sacroiliac joint (SIJ) $[7,38]$. This area is poorly visualized in plain radiographs, and the residual displacement is often missed. It may lead to post-traumatic arthrosis and be a generator of chronic pain. SIJ instability most often occurs in vertically unstable fractures. Up to $45 \%$ of these are caused by sacral fractures and may also be a source of pain [42]. Pain in the SIJ area can also be caused by trauma to the lumbar spine, osteoarthritis of the facet joints, and also be neurogenic in nature caused by damage to the lumbosacral plexus. Anterior semiring nonunion is easier tolerated and less likely to cause pelvic pain [33], and less frequent clinical manifestations often lead to late diagnosis [7].

Global body imbalance Fractures of type C according to Tile $\mathrm{M}$. with displacement of the hemipelvis can lead to a misalignment of the pelvis, imbalance in the sitting and/or standing position, difference in leg length. Deformities occurring in the SIJ area are the most severe, causing compensatory curvature of the spine. Asymmetry is due to vertical displacement and rotation of the hemipelvis in the sagittal plane [34]. Position of the ischial tubercles at different levels causes pain and discomfort in the sitting position $[24,31]$, which is clinically observed in $50 \%$ of patients [43]. In bilateral cranial displacement of pelvic bones, the coccyx may be a source of pain and cause discomfort in the sitting position [34, 35, 38].

Limb length discrepancy occurs in vertical and rotational displacement of the hemipelvis, as well as a two-column fracture of the acetabulum. Significant shortening is detected clinically in $25-34 \%$ of patients $[12,43]$. Lower limb internal rotation occurs in lateral compression, and external rotation in case of open- book fractures.
Treatment Stable deformities with slight displacement are well tolerated by many patients and do not require surgical treatment [31, 38]. Conservative management of these patients and correction of the length of the limbs with orthopedic shoes is possible.

The main indication for surgical treatment is pain caused by severe deformation of the pelvic ring or nonunion of the pelvic bones $[12,43,44]$. Foreign authors offer open operations [7, 37, 45] with an extensive release of soft tissues [44]. These operations are complex, multi-stage (two or three stages), may last for more than 6 hours and require transfusion of donated blood [7, 31-33, 43, 44, 46, 47].

Correction is easier in pelvic deformity with isolated internal or external rotation of the hemipelvis [41, 44]. Pfannenstiel and modified Stoppa approaches are recommended, along with bone autoplasty and addition of bone morphogenetic protein (BMP), if possible; a $3.5-\mathrm{mm}$ reconstructive plate is used for fixation $[38,48]$. Fixation with two plates was described if previous osteosynthesis had failed [32]. In some cases, symphysiodesis is performed to restore the integrity of the pelvic ring. Stabilization of the posterior semiring is performed with iliosacral screws, plates or sacral braces $[30,31,37,39]$. Kanezaki and Rommens used lumbariliac fixation with a spinal system in combination with the installation of additional sacral tightening through the body of the S1 vertebra for bilateral fractures of the lateral sacrum mass in a patient with low bone density [23]. The dorsal approach is recognized as the most optimal for surgical treatment of sacral nonunions [39].

Reconstruction in gross deformities of the pelvis is technically more complex than the treatment of an acute fracture [31, 49, 50, 51]. It requires a thorough knowledge of anatomy, surgical approaches, reduction techniques, and various fixation options used in fractures of the pelvic bones. In most cases, reconstruction is performed in three stages at $540^{\circ}$ : 1) anteroior-posterior-anterior approach; 2) posterioranterior-posterior, with a need to change the position of the patient $[31,33,35,38]$. To expose the anterior semiring, the Pfannenstiel or ilio-inguinal approaches are used. To work on the posterior semiring, the posterior vertical and iliac approaches are used.

It is recommended to perform the osteotomy for deformity correction in the area of malunion $[31,35$, 52]. To reduce the hemipelvis, laminar excision of the sacro-tuberous, sacrospinous, and iliolumbar ligaments is performed [33, 35, 38]. Hemipelvis transposition should be performed under neurophysiological control $[31,34,38]$. Similar to acute injuries, internal fixation is preferred. However, the need for mechanical stability in case of pelvic instability and revision interventions is greater than in fractures [31, 37, 43]. Kurz et. al. propose to perform osteotomy of the ilium in combination with 
symphysitomy followed by bone osteosynthesis to correct the deformity of the pelvic ring and equalize the length of the legs [43]. This technique may correct the deformity in two steps without changing the position of the patient on the operating table. Domestic authors recommend using external fixation devices for pelvic deformities [1, 16, 45]. I.L. Shlykov (2009) proposes a combined method of treating patients. He corrects gross deformities of the pelvic ring by maneuvers with an external fixation device of his own construction and fixes pelvic fragments combining various options of internal osteosynthesis [17].

The main advantages of this approach are low trauma, gradual correction of deformity, and possibility to perform compression in dynamics $[3,5]$. However, there are a number of significant shortcomings such as long-term immobilization; high risk of superficial and deep wound infection, including during conversion to internal osteosynthesis; impossible reduction with the AEF due to rigid scar tissue [22, 24, 39].

Cano-Luís et al use a sequential three-stage correction option for pelvic deformities and leg length discrepancy of more than $3 \mathrm{~cm}$. Stage 1 is mobilization of the hemipelvix with the removal of scar tissue and corrective osteotomy of the pelvic bones; Stage 2 is skeletal traction through the femur to protect the hip joint for 7-10 days; Stage 3 is internal osteosynthesis with fixation of the anterior and posterior pelvic semirings [38]. However, the use of such a surgical intervention requires high qualifications of the surgeon, power equipment in the operating room and bone sets, intraoperative fluoroscopy, and neurophysiological monitoring.

\section{CONCLUSION}

Growth in the number of pelvic ring injuries results in increase of unsatisfactory outcomes.

Instability with clinical manifestations of nonunion and pain are the leading symptoms along with an imbalance syndrome, manifested by the formation of a gross deformation of the pelvic ring.
Syndromic assessment determines the tactics of surgical treatment.

A detailed planning of the intervention stages, level of osteotomy, and combination of osteosynthesis options using spinal fixation systems assist in solving the problems of reconstructive pelvic surgery in one session.

\section{REFERENCES}

1. Shlykov I.L., Kuznetsova N.L. Algoritm vybora metoda operativnogo lecheniia bolnykh s posttravmaticheskimi deformatsiiami tazovogo koltsa [Algorithm of selecting the technique of surgical treatment of patients with pelvic ring posttraumatic deformities]. Genij Ortopedii, 2010, no. 2, pp. 70-73. (in Russian)

2. Tile M., Kellam J., Helfet D., eds. Fractures of the pelvis and acetabulum. $3^{\text {rd }}$ Edition. Lippincott, Williams \& Wilkins. 2003.600 p.

3. Cherkes-Zade D.I. Lechenie povrezhdenii taza i ikh posledstvii: ruk. dlia vrachei [Treatment of the pelvis injuries and their consequences: guide for physicians]. M., Meditsina, 2006, 191 p. (in Russian)

4. Grishchuk M.E., Puseva N.V. Tishkov V.Iu., Vasilev V.Iu. Operativnoe lechenie nesvezhikh i zastarelykh dvustoronnikh rotatsionno-nestabilnykh povrezhdenii taza (obzor literatury) [Surgical treatment of stale and long-standing bilateral rotationally unstable pelvic injuries (review of the literature)]. Biulleten Vostochno-Sibirskogo Nauchnogo Tsentra Sibirskogo Otdeleniia Rossiiskoi Akademii Meditsinskikh Nauk, 2010, no. 5 (75), pp. 222-232. (in Russian)

5. Martel I.I., Shvedov V.V. Vozmozhnosti vneshnei fiksatsii po printsipam Ilizarova pri zakrytom vosstanovlenii formy i stabilnosti tazovogo koltsa $\mathrm{u}$ bolnykh s zastarelymi povrezhdeniiami taza [Possibilities of external fixation according to Ilizarov principles for closed restoration of pelvic ring shape and stability in patients with advanced pelvic injuries]. Genij Ortopedii, 2013, no. 2, pp. 5-9. (in Russian)

6. Sergeev S.V., Ananin D.A., Grishanin O.B. Dinamicheskaia plastina dlia fiksatsii perednego polukoltsa taza pri nestabilnykh povrezhdeniiakh tazovogo koltsa [A dynamic plate for fixing the anterior pelvic semi-ring in case of unstable injuries of the pelvic ring]. Klinicheskii Opyt Dvadtsatki, 2013, no. 4 (20), pp. 57-62. (in Russian)

7. Tripathy S.K., Goyal T., Sen R.K. Nonunions and malunions of the pelvis. Eur. J. Trauma Emerg. Surg., 2015 , vol. 41, no. 4, pp. 335-342. DOI: $10.1007 / \mathrm{s} 00068-014-0461-0$

8. Giannoudis P.V., Psarakis S., Kanakaris N.K., Pape H.C. Biological enhancement of bone healing with bone morphogenetic protein-7 at the clinical setting of pelvic girdle non-unions. Injury, 2007, vol. 38, no. Suppl. 4, pp. S43-S48. DOI: 10.1016/s0020-1383(08)70008-1

9. Lindahl J. Delayed and late reconstructions of the pelvis. Suom. Ortop. Traumatol., 2011, vol. 34, no. 1, pp. 43-48.

10. Borozda I.V. Sistematizatsiia znanii po biomekhanike tazovogo koltsa [Systematization of knowledge in biomechanics of the pelvic ring]. Dalnevostochnyi Meditsinskii Zhurnal, 2009, no. 2, pp. 129-132. (in Russian)

11. Runkov A.V., Kutepov S.M., Stelmakh K.K. Antoniadi Yu.V. Ustranenie travmaticheskikh deformatsii taza // lechenie povrezhdenii i zabolevanii kostei taza [Elimination of traumatic pelvic deformities]. Materialy iubileinoi mezhdun. nauch.-prakt. konf. travmatologov-ortopedov "Novye tekhnologii v lechenii povrezhdenii i zabolevanii oporno-dvigatelnoi sistemy" [Proceedings of Anniversary International Scientific-and-Practical Conference of Traumatologists and Orthopedists]. Ekaterinburg, 2001, pp. 48-50. (in Russian)

12. Kanakaris N.K., Angoules A.G., Nikolaou V.S., Kontakis G., Giannoudis P.V. Treatment and outcomes of pelvic malunions and nonunions: a systematic review. Clin. Orthop. Relat. Res., 2009, vol. 467, no. 8, pp. 2112-2124. DOI: 10.1007/s11999-009-0712-2

13. Ziran B.H., Chamberlin E., Shuler F.D., Shah M. Delays and difficulties in the diagnosis of lower urologic injuries in the context of pelvic fractures. J. Trauma, 2005, vol. 58, no. 3, pp. 533-537. DOI: 10.1097/01.ta.0000152561.57646.80

14. Shchetkin V.A., Chernyshev A.S., Ivanov P.A., Fain A.M., Chukina E.A., Vorontsova Iu.A. Metodika rannei reabilitatsii u patsientov s povrezhdeniem tazovogo koltsa [The technique of early rehabilitation in patients with the pelvic ring damage]. Fizioterapiia, Balneologiia $i$ Reabilitatsiia, 2013, no. 4, pp. 13-16. (in Russian)

15. Tiliakov A.B., Valiev E.Iu., Ubaidullaev B.S. Primenenie sterzhnevogo apparata vneshnei fiksatsii v kompleksnom lechenii nestabilnykh perelomov kostei taza pri sochetannoi travme [The use of a rod device for external fixation in the complex treatment of unstable fractures of pelvic bones in case of concomitant injury]. Zhurnal im. N.V. Sklifosovskogo "Neotlozhnaia Meditsinskaia Pomoshch», 2014, no. 2, pp. 32-37. (in Russian)

16. Smirnov A.A., Pavlov D.V. Operativnoe lechenie nestabilnykh povrezhdenii taza i ikh posledstvii [Surgical treatment of unstable pelvic injuries and their consequences]. Meditsinskii Almanakh, 2012, no. 5, pp. 148-151. (in Russian)

17. Shlykov I.L., Kuznetsova N.L. Kompleksnoe lechenie bolnykh s nestabilnymi perelomami taza na osnove lechebno-diagnosticheskikh algoritmov [Complex treatment of patients with unstable pelvic fractures on the basis of treatment and diagnostic algorithms]. Sistemnaia Integratsiia $v$ Zdravookhranenii, 2009, no. 4, pp. 3-9. (in Russian)

18. Bignardi C., Terzini M., Aprato A., Audenino A.L., Costa P., Massai D., Massè A., Zanetti E.M. Pelvic manipulator for fractures reduction. International Journal of Mechanical Engineering and Technology, 2018, vol. 9, no. 3, pp. 570-580.

19. Wu X., Li Y., Sun X., Wang J., Zhao C., Yang M., Zhu S., Cao Q., Wu H., Wang M. Modeling of unstable pelvic fractures for $20^{\circ}$ sagittally rotated pelvic displacement. Med. Eng. Phys., 2015, vol. 37, no. 11, pp. 1076-1081. DOI: 10.1016/j.medengphy.2015.08.015

20. Dimitriou R., Giannoudis P.V. Pelvic fractures. Surgery (Oxford), 2012, vol. 30, no. 7, pp. 339-346. 
21. Eckardt H., Egger A., Hasler R.M., Zech C.J., Vach W., Suhm N., Morgenstern M., Saxer F. Good functional outcome in patients suffering fragility fractures of the pelvis treated with percutaneous screw stabilisation: Assessment of complications and factors influencing failure. Injury, 2017, vol. 48, no. 12 , pp. 2717-2723. DOI: $10.1016 /$ j.injury.2017.11.002

22. Zamzam M.M. Unstable pelvic ring injuries. Outcome and timing of surgical treatment by internal fixation. Saudi Med. J., 2004, vol. 25, no. 11, pp. 1670-1674.

23. Kanezaki S., Rommens P.M. Bilateral nonunion of the sacrum in a long-term paraplegic patient treated with trans-sacral bar and spinopelvic fixation. Arch. Orthop. Trauma Surg., 2015, vol. 135, no. 3, pp. 345-349. DOI: 10.1007/s00402-014-2143-0

24. Witvliet M.J., Ping Fung Kon Jin P.H., Goslings J.C., Luitse J.S., Ponsen K.J. Historical treatment results of pelvic ring fractures: a 12-year cohort study. Eur. J. Trauma Emerg. Surg., 2009, vol. 35, no. 1, pp. 43-48. DOI: 10.1007/s00068-008-7107-z

25. Akbar M., Arshad R.M., Hanif M., Rana R.E. Treatment of open book pelvic fractures: Comparison between internal and external fixation. Pakistan Journal of Medical and Health Sciences, 2012, vol. 6, no. 3, pp. 662-665.

26. Iorio J.A., Jakoi A.M., Rehman S. Percutaneous Sacroiliac Screw Fixation of the Posterior Pelvic Ring. Orthop. Clin. North Am., 2015, vol. 46, no. 4, pp. 511-521. DOI: 10.1016/j.ocl.2015.06.005

27. Blum L., Hake M.E., Charles R., Conlan T., Rojas D., Martin M.T., Mauffrey C. Vertical shear pelvic injury: evaluation, management, and fixation strategies. Int. Orthop., 2018, vol. 42, no. 11, pp. 2663-2674. DOI: 10.1007/s00264-018-3883-1

28. Dienstknecht T., Pfeifer R., Horst K., Sellei R.M., Berner A., Zelle B.A., Probst C., Pape H.C. The long-term clinical outcome after pelvic ring injuries. Bone Joint J., 2013, vol. 95-B, no. 4, pp. 548-553. DOI: 10.1302/0301-620X.95B4.30804

29. Hessmann M.H., Rickert M., Hofmann A., Rommens P.M., Buhl M. Outcome in pelvic ring fractures. Eur. J. Trauma Emerg. Surg., 2010, vol. 36, no. 2, pp. 124-130. DOI: 10.1007/s00068-010-1042-0

30. Acklin Y.P., Marco G., Sommer C. Double locking plate fixation of sacral fractures in unstable pelvic ring C-type injuries. Oper. Orthop. Traumatol., 2015, vol. 27, no. 1, pp. 74-79. DOI: 10.1007/s00064-014-0307-2

31. Vanderschot P., Daenens K., Broos P. Surgical treatment of post-traumatic pelvic deformities. Injury, 1998, vol. 29, no. 1, pp. 19-22. DOI: 10.1016 s0020-1383(97)00111-3

32. Rousseau M.A., Laude F., Lazennec J.Y., Saillant G., Catonné Y. Two-stage surgical procedure for treating pelvic malunions. Int. Orthop., 2006, vol. 30, no. 5, pp. 338-341. DOI: 10.1007/s00264-006-0089-8

33. Lee K.J., Min B.W., Oh G.M., Lee S.W. Surgical correction of pelvic malunion and nonunion. Clin. Orthop. Surg., 2015 , vol. 7, no. 3, pp. 396-401. DOI: $10.4055 /$ cios.2015.7.3.396

34. Mears D.C., Velyvis J. Surgical reconstruction of late pelvic post-traumatic nonunion and malalignment. J. Bone Joint Surg. Br., 2003, vol. 85, no. 1, pp. 21-30. DOI: 10.1302/0301-620x.85b1.13349

35. Matta J.M., Dickson K.F., Markovich G.D. Surgical treatment of pelvic nonunions and malunions. Clin. Orthop. Relat. Res., 1996, no. 329, pp. 199206. DOI: $10.1097 / 00003086-199608000-00024$

36. Wright J.L., Nathens A.B., Rivara F.P., MacKenzie E.J., Wessells H. Specific fracture configurations predict sexual and excretory dysfunction in men and women 1 year after pelvic fracture. J. Urol., 2006, vol. 176, no. 4, Pt. 1, pp. 1540-1545. DOI: 10.1016/j.juro.2006.06.044

37. Gautier E., Rommens P.M., Matta J.M. Late reconstruction after pelvic ring injuries. Injury, 1996, vol. 27, no. Suppl. 2, pp. B39-B46

38. Cano-Luís P., Giráldez-Sánchez M.Á., Andrés-Cano P. Pelvic post-traumatic asymmetry: Assessment and sequenced treatment. EFORT Open Rev., 2018, vol. 3, no. 5, pp. 335-346. DOI: 10.1302/2058-5241.3.170069

39. Keating J. Delayed reconstruction of pelvic fractures. Orthop. \& Trauma. Mini-symposium: Pelvic Fractures, 2005, vol. 19, no. 5, pp. 362-372. DOI: 10.1016/j.cuor.2005.09.006

40. Van den Bosch E.W., Van der Kleyn R., Van Zwienen M.C.M.A., Van Vugt A.B. Nonunion of unstable fractures of the pelvis. Eur. J. Trauma, 2002, vol. 28, pp. 100-103. DOI: https://doi.org/10.1007/s00068-002-1188-x

41. Taguchi T., Kawai S., Kaneko K., Yugue D. Surgical treatment of old pelvic fractures. Int. Orthop., 2000, vol. 24, no. 1, pp. 28-32. DOI: 10.1007/ s002640050007

42. Oliver C.W., Twaddle B., Agel J., Routt M.L. Jr. Outcome after pelvic ring fractures: evaluation using the medical outcomes short form SF-36. Injury, 1996, vol. 27, no. 9, pp. 635-641. DOI: 10.1016/s0020-1383(96)00100-3

43. Kurz S., Pieroh P., Lenk M., Josten C., Böhme J. Three-dimensional reduction and finite element analysis improves the treatment of pelvic malunion reconstructive surgery: a case report. Medicine (Baltimore), 2017, vol. 96, no. 42, pp. e8136. DOI: 10.1097/MD.0000000000008136

44. Oransky M., Tortora M. Nonunions and malunions after pelvic fractures: why they occur and what can be done? Injury, 2007, vol. 38, no. 4, pp. 489496. DOI: 10.1016/j.injury.2007.01.019

45. Khabibianov R.Ia., Galeev I.G. Artrodezirovanie kresttsovo-podvzdoshnogo sochleneniia [Arthrodesis of the sacroiliac joint]. Prakticheskaia Meditsina, 2014, no. 4-2 (80), pp. 152-155. (in Russian)

46. Guimarães J.A.M., Rocha V.M.D., Barcellos A.L.L. Osteotomia sacroilíaca posterior: uma opção ao acesso ilioinguinal na reconstrução pélvica em lesões inveteradas [Posterior sacroiliac osteotomy: an alternative to the ilioinguinal approach for pelvic reconstruction in misalignment lesions]. Rev. Bras. Ortop., 2017, vol. 52, no. Suppl. 1, pp. 63-68. DOI: 10.1016/j.rboe.2017.08.010. (in Brazilian)

47. Taller S., Srám J., Lukás R., Krivohlávek M. Paklouby pánve [Nonunions or malunions of pelvic fractures]. Acta Chir. Orthop. Traumatol. Cech., 2009, vol. 76, no. 2, pp. 121-127. (in Czech)

48. Fang C., Alabdulrahman H., Pfeifer R., Tarkin I.S., Pape H.C. Late reconstruction of severe open-book deformities of the pelvis - tips and tricks. Int. Orthop., 2017, vol. 41, no. 9, pp. 1777-1784. DOI: 10.1007/s00264-017-3549-4

49. Blohm D., Madsen F., Jensen J. Pelvisfrakturer - en opgørelse af operationsresultater of baekken "nonunion" og "malunion" [Fractures of the pelvis-a survey of" nonunion" and" malunion" surgical results]. Ugeskr. Laeger., 2000, vol. 162, no. 47, pp. 6413-6415. (in Danish)

50. Hessmann M.H., Ingelfinger P., Hofmann A., Rommens P.M. Sekundär- und Späteingriffe nach Beckenring- und Azetabulumfrakturen [Secondary and late interventions after fractures of the pelvic ring and aetabulum]. Trauma und Berufskrankheit, 2007, vol. 9, no. 2, pp. S172-S178. DOI: 10.1007/ s10039-006-1138-7 (in German)

51. Nicodemo A., Capella M., Deregibus M., Massè A. Nonunion of a sacral fracture refractory to bone grafting: internal fixation and osteogenic protein-1 (BMP-7) application. Musculoskelet. Surg., 2011, vol. 95, no. 2, pp. 157-161. DOI: 10.1007/s12306-011-0131-x

52. Zhang L.-C., Lan X., Zhang L., Tao Sh., Zhang Q., Liang X.-D., Guo Y.-Z., Tang P.-F. Internal fixation with different implants for the treatment of old pelvic fractures. Chinese Journal of Tissue Engineering Research, 2013, vol. 17, no. 9, pp. 1703-1710. DOI: 10.3969/j.issn.2095-4344.2013.09.027

53. Zhdanov A.S., Gubin A.V. Sposob rekonstruktsii taza pri slozhnykh posttravmaticheskikh deformatsiiakh [The way of pelvis reconstruction for complex posttraumatic deformities]. Patent RF no. 2637283, A61B 17/56, 2016. (in Russian)

Received: 25.03 .2020

\section{Information about the authors:}

1. Kairat L. Zhalmagambetov,

Ilizarov National Medical Research Centre for Traumatology and Orthopedics, Kurgan, Russian Federation

2. Sergey O. Ryabykh, M.D., Ph.D.,

Ilizarov National Medical Research Centre for Traumatology and Orthopedics, Kurgan, Russian Federation,

Email: rso_@mail.ru

3. Alexey S. Zhdanov, M.D.,

Ilizarov National Medical Research Centre for Traumatology and Orthopedics, Kurgan, Russian Federation,

Email: too2@rncvto.ru

4. Alexander V. Gubin, M.D., Ph.D.,

National Medical Research Center of Traumatology and Orthopedics n.a. N.N. Priorov, Moscow, Russian Federation,

Email: shugu19@gubin.spb.ru 